\title{
MODAL SOSIAL SEBAGAI STRATEGI BERTAHAN HIDUP BURUH TANI DI DESA KOPIWANGKER, KECAMATAN LANGOWAN BARAT, MINAHASA
}

\author{
Wolter Widyatama Hutapea \\ Benu Olfie L.S. \\ Charles R. Ngangi
}

\begin{abstract}
This research aims to determine and describe how farm-workers can survive by social strategy as their strategy. From the three elements of social capital, that's trust, norms, and networks, which one has the greater influence for a survival strategy of Kopiwangker farm-workers in village. This research was conducted over five months, from February until June 2016 started from preparation until making research reports. This study has used primary data and secondary data. The number of respondents is 30 respondents of whom are farm-workers. The sampling method which used in this research is purposive sampling and data analysis method used is descriptive qualitative which quantified using the Likert Scale. The results of this research indicate that social capital can be a survival strategy for Kopiwangker village farm-workers, especially on the elements of the network (patron-client networks) because it has the highest score, that is 450. But according to several informants that ever happened was also a problem among some farm-workers (as clients) and patrons, but always can be resolved.
\end{abstract}

Key words: social capital, survival strategy, farm-workers, Kopiwangker Village, Minahasa

\begin{abstract}
ABSTRAK
Penelitian ini bertujuan untuk mengetahui dan mendeskripsikan bagaimana para buruh tani di Desa Kopiwangker dapat bertahan hidup berdasarkan modal sosial sebagai strateginya. Dari ketiga unsur modal sosial, yaitu kepercayaan, norma, dan jaringan, manakah yang memiliki pengaruh lebih besar bagi strategi bertahan hidup buruh tani di Desa Kopiwangker. Penelitian ini dilaksanakan selama 5 bulan, dari bulan Februari sampai bulan Juni 2016 mulai dari persiapan sampai penyusunan laporan penelitian. Penelitian ini mengunakan data primer dan data sekunder. Jumlah responden sebanyak 30 responden yang semuanya adalah buruh tani. Metode pengambilan sampel dalam penelitian ini menggunakan metode purposive sampling. Metode analisis data yang digunakan adalah deskriptif kualitatif yang di kuantitatifkan dengan Skala Likert. Hasil penelitian ini menunjukkan bahwa modal sosial dapat menjadi strategi bertahan hidup buruh tani di Desa Kopiwangker, khususnya pada unsur jaringan (jaringan patron-klien) karena memiliki skor tertinggi, yaitu 450. Tetapi menurut beberapa informan bahwa pernah terjadi juga masalah di antara beberapa buruh tani (sebagai klien) dan patron, tetapi selalu bisa diselesaikan dengan baik.
\end{abstract}

Kata kunci: modal sosial, strategi bertahan hidup, buruh tani, Desa Kopiwangker, Minahasa

\section{PENDAHULUAN}

\section{Latar Belakang}

Indonesia dikenal sebagai salah satu negara agraris yang sebagian besar penduduknya bekerja sebagai petani, namun saat ini jumlah rumah tangga petani menurun. Menurut data BPS dari hasil Sensus Pertanian dari tahun 2003 sampai 2013, jumlah rumah tangga petani menurun dari 31.000.000 menjadi 26.000.000. Data statistik tahun 2013 menyatakan bahwa luas lahan pertanian di Indonesia adalah 25.261.879 $\mathrm{Ha}$

Petani merupakan pekerjaan sebagian besar penduduk Indonesia. Petani adalah orang yang melakukan kegiatan bercocok tanam hasil 
bumi atau memelihara ternak dengan tujuan untuk memperoleh kehidupan dari kegiatan yang dilakukannya tersebut (Rodjak, 2002, dalam Tapi, 2014)

Pada kenyataannya sektor pertanian kurang terpantau dan kesejahteraan para Petani kurang diperhatikan. Menurut data BPS pada Maret 2011 ada 57,78 \% penduduk miskin Indonesia bekerja pada sektor Pertanian, baik itu petani atau buruh tani dan sebagian besar terpusat di daerah-daerah pedesaan sebagai wilayah bermukim para petani. Mendukung pernyataan tersebut, Boeke dalam Yustika dan Baks (2015) menggambarkannya dalam pengertian desa secara sempit, yaitu suatu masyarakat para petani yang mencukupi hidup sendiri (swasembada). Dengan gambaran tersebut, adalah benar jika sebagian besar penduduk desa merupakan kelompok masyarakat miskin (Yustika dan Baks, 2015).

Petani di Indonesia mayoritas masuk dalam golongan petani kecil yang di dalamnya termasuk juga buruh tani. Buruh tani adalah petani yang bekerja di ladang milik orang lain dengan tujuan untuk mendapat upah. Buruh tani termasuk dalam golongan buruh harian lepas (BHL) yang memiliki pengertian buruh yang diikat dengan hubungan kerja dari hari ke hari dan menerima upah sesuai dengan banyaknya hari kerja atau jam kerja atau banyaknya barang atau jenis pekerjaan yang disediakan (Sembiring, 2009).

Sastraatmadja (2006) dalam Sunarti dan Khomsan (2012) mengatakan bahwa petani hidup dalam ketertinggalan dengan kondisi kehidupan yang mengenaskan. Kenyataan yang ada masih menunjukkan bahwa sebagian penduduk dan rumah tangga miskin masih mengandalkan pertanian sebagai pekerjaan utama (Dillon dan Hermanto, 1993 dalam Faturochman dan Molo, 1994).

Ada dua masalah mendasar pada sektor pertanian di Indonesia (Yustika dan Baks, 2015): yang pertama adalah masalah kepemilikan lahan yang kecil. Jika pada tahun 1980-an, Hayami dan Kikuchi melaporkan bahwa kepemilikan lahan rata-rata di pulau Jawa kurang dari 0,5 hektar, maka sekarang ini rata-rata hanya 0,25 hektar saja. Kedua adalah menyingkirkan kondisi-kondisi yang menyebabkan sektor pertanian (petani) selama ini sebagai pihak yang selalu kalah dan tersingkirkan. Berhadapan dengan alam, teknologi, dan kelembagaan; sektor pertanian selama ini hampir selalu berada pada situasi subordinat; terdesak secara mengenaskan (Soetomo dalam Yustika dan Baks, 2015).

Badan Kependudukan dan Keluarga Berencana Nasional (BKKBN) memberi kriteria keluarga miskin atau keluarga PraSejahtera, yaitu sebagai keluarga yang belum dapat memenuhi salah satu atau lebih dari 5 kebutuhan dasarnya (basic needs), seperti kebutuhan akan pengajaran agama, pangan, papan, sandang dan kesehatan, sedangkan BPS memiliki 14 kriteria keluarga miskin, yaitu Luas lantai bangunan tempat tinggal kurang dari $8 \mathrm{~m} 2$ per orang, Jenis lantai tempat tinggal terbuat dari tanah/bambu/kayu murahan, Dinding tempat tinggal dari bambu/ rumbia/ kayu berkualitas rendah/tembok tanpa diplester, Tidak memiliki fasilitas buang air besar/ bersama-sama dengan rumah tangga lain, Sumber penerangan rumah tangga tidak menggunakan listrik, Sumber air minum berasal dari sumur/mata air tidak terlindung/ sungai/air hujan, Bahan bakar untuk memasak sehari-hari adalah kayu bakar/arang/ minyak tanah, Hanya mengkonsumsi daging/susu/ayam dalam satu kali seminggu, Hanya membeli satu stel pakaian baru dalam setahun, Hanya sanggup makan sebanyak satu/ dua kali dalam sehari, Tidak sanggup membayar biaya pengobatan di puskesmas/ poliklinik, Sumber penghasilan kepala rumah tangga adalah: petani dengan luas lahan 500m2, buruh tani, nelayan, buruh bangunan, buruh perkebunan dan atau pekerjaan lainnya dengan pendapatan dibawah Rp. 600.000,- per bulan, Pendidikan tertinggi kepala rumah tangga: tidak sekolah/ tidak tamat $\mathrm{SD} /$ tamat SD, Tidak memiliki tabungan/ barang yang mudah dijual dengan minimal Rp. 500.000,- seperti sepeda motor kredit/ non kredit, emas, ternak, kapal motor, atau barang modal lainnya.

Maslow dalam Fiedhawatie (2013) menyatakan ada 5 hierarkhi kebutuhan hidup manusia, yaitu kebutuhan fisiologis, keamanan, cinta (kasih sayang), dihargai, dan aktualisasi diri, dan dari semua kebutuhan tersebut kebutuhan yang paling dasar adalah kebutuhan fisiologis yang di dalamnya ada makanan, minuman, pakaian, oksigen, dan sebagainya. 
Ketika kebutuhan yang dasar seperti makanan dan minuman tidak dapat terpenuhi maka itu dapat menjadi pemicu seseorang untuk melakukan tindakan diluar akal sehat seperti tindakan-tindakan kriminal dan kejahatan, atau juga yang bisa disebut sebagai penyakit sosial atau patologi sosial. Mendukung pernyataan tersebut Kartono (2014) menjelaskan bahwa kriminalitas atau kejahatan itu bukan peristiwa bawaan atau herediter yang dimiliki seseorang melainkan terjadi karena seseorang merasa ada paksaan yang sangat kuat dalam dirinya untuk bisa mempertahankan hidupnya. Hal ini juga yang dapat dialami para petani miskin.

Dalam usaha menanggulangi setiap masalah yang dihadapi para petani, dalam hal ini termasuk kemiskinan, kita harus mencari setiap sumber dan sebab permasalahan, dan mencari jalan keluar untuk memecahkannya. Suyono, dalam Anwas (2013) mengatakan bahwa penuntasan kemiskinan menuju keluarga sejahtera tidak hanya persoalan variabel ekonomi tetapi perlu memasukan variabel nonekonomi. Hal ini disebabkan karena penuntasan kemiskinan tidak hanya meningkatkan pendapatan, tetapi perlu dilakukan secara holistik yang menyangkut aspek kehidupan dasar manusia. Salah satu titik permasalahan yang harus diperhatikan dari para petani yaitu dari aspek sosial. Dalam menghadapi masalah yang ada maka ada faktor-faktor yang perlu diperhatikan dari aspek sosial seperti kepercayaan, norma, dan jaringan, ketiganya adalah unsur modal Sosial.

Petani mulai berpikir untuk bertahan hidup ketika dia sadar bahwa kebutuhan hidupnya dan keluarganya tinggi dan ini mendesak petani untuk berusaha memenuhi kebutuhan-kebutuhan itu. Scott dalam Kumesan, dkk (2015) mengemukakan bahwa dengan kebutuhan hidup yang besar memacu petani untuk berperilaku sebagai petani survival untuk memenuhi kebutuhannya. Scott, (1981) dalam Khotijah dan Purnomo (2014) berkata mekanisme bertahan hidup sebagai upaya yang dilakukan kelompok miskin guna mempertahankan hidupnya.

$$
\text { Putnam dalam Anam (2013) }
$$

mendefinisikan modal sosial sebagai penampilan organisasi sosial seperti jaringan dan kepercayaan yang memfasilitasi adanya koordinasi dan kerjasama bagi keuntungan bersama. Sedangkan Coleman dalam Mariani (2014), mendefinisikan modal sosial sebagai seperangkat sumber daya yang melekat pada hubungan keluarga da

n dalam organisasi sosial komunitas dan yang berguna bagi perkembangan kognitif atau sosial anak atau orang yang masih muda. Sumber-sumber daya tersebut berbeda bagi orang-orang yang berlainan dan dapat memberikan manfaat penting bagi anak-anak dan remaja dalam perkembangan modal manusia mereka.

Budaya adat istiadat yang masih mengakar, pola hidup masyarakat di desa tertinggal masih mewarisi nenek moyangnya. Tradisi ini pula yang menjadikan aktivitas penduduk desa sarat dengan modal sosial (Yustika dan Baks, 2015). Perbedaan pencapaian pembangunan desa tidak bisa dijelaskan secara tunggal lewat perbedaan input-input material, semacam sumber daya alam, teknologi, pendidikan, ataupun kepadatan penduduk; melainkan mempertimbangkan modal sosial sebagai determinan penting dalam pelaksanaan pembangunan, seperti nilai-nilai, norma, jaringan sosial, dan distribusi pengetahuan (Dhesi dalam Yustika dan Baks, 2015). Akashiro dalam Suryadi, dkk (2013) mengungkapkan bahwa petani dengan segenap kemampuannya berusaha memutuskan isolasi yang menghambat komunikasi survivor dengan masyarakat umum, dari pernyataan tersebut berarti petani berusaha untuk membangun suatu hubungan dengan masyarakat sekitarnya untuk bisa bertahan hidup.

Sektor pertanian di Provinsi Sulawesi Utara memiliki peran yang penting, terbukti dalam Data statistik daerah Provinsi Sulawesi Utara tahun 2015 tercatat bahwa struktur perekonomian di Sulawesi Utara pada tahun 2014 didominasi dengan jelas oleh pertanian, kehutanan, dan perikanan dengan kontribusi sebesar 22,08\%

Berdasarkan data Sulawesi Utara dalam Angka tahun 2015 dari katalog BPS, Luas lahan sawah dan lahan kering menurut penggunaannya di tiap Kabupaten dan Kota di Provinsi Sulawesi Utara berjumlah 1.544.199 hektar secara keseluruhan, yang terbagi atas lahan Irigasi 51.618 hektar, tadah hujan 10.792 hektar, rawa pasang surut lainnya 364 hektar, rawa lebak 71 hektar, tegal dan kebun 191.816 
hektar, ladang dan huma 112.408 hektar, perkebunan 307.487 hektar, lahan tanaman kayu-kayuan dan hutan rakyat 153.373 hektar, pengembalaan dan padang rumput 24.797 hektar, lahan sementara tak diusahakan 68.136 hektar, lainnya (tambak/kolam/empang/hutan negara/rawa) 82.240 hektar, dan lahan bukan pertanian 541.097 hektar.

Daerah Minahasa merupakan kabupaten yang penduduknya banyak bermata pencaharian sebagai petani. Menurut data statistik potensi desa Provinsi Sulawesi Utara tahun 2014 dikatakan bahwa di Kabupaten Minahasa ada sekitar 226 desa yang sebagian besar penduduknya bekerja sebagai petani. Salah satu Kecamatan di Kabupaten Minahasa yang pekerja bidang pertaniannya sangat tinggi adalah Kecamatan Langowan Barat.

Desa yang menjadi lokasi penelitian ini adalah Desa Kopiwangker, Kecamatan Langowan Barat. Lokasi ini layak untuk menjadi lokasi penelitian karena berdasarkan hasil Pra-Survey yang telah dilakukan lokasi ini hampir semua penduduknya berprofesi sebagai petani. Berdasarkan hasil Pra-Survey dan wawancara terhadap hukum tua, $80 \%$ dari penduduk Desa Kopiwangker bekerja sebagai Petani, baik sebagai petani pemilik lahan, buruh tani, dan penggarap (Tumoyo menurut bahasa setempat.

Profil singkat dari Desa Kopiwangker berdasarkan hasil dari wawancara dengan hukum tua desa adalah: Luas lahan 62 hektar (pertanian dan perkebunan 40 hektar, pemukiman 20 hektar, dan 2 hektar untuk pekuburan dan balai desa), jumlah penduduk 1039 jiwa, jumlah Kepala keluarga 340, jumlah Kepala keluarga kurang mampu 143 tapi yang tercatat sebagai penerima raskin ada 117 Kepala keluarga. Berdasarkan hasil wawancara dengan hukum tua desa, menurut beliau keadaan sosial di Desa Kopiwangker baik, dan hukum kasih yang ada di desa itu kuat, jaringan sosial bisa tercipta di antara setiap warga desa. Tujuan dari penelitian ini untuk mendeskripsikan bagaimana para buruh tani di Desa Kopiwangker dapat bertahan hidup dengan membangun nilai modal sosial.

\section{Perumusan Masalah}

Berdasarkan latar belakang, buruh tani di Desa Kopiwangker bertahan hidup tidak hanya dilihat dari sisi ekonomi, tapi perlu memperhatikan dari sisi sosial untuk mengetahui apakah buruh tani di Desa Kopiwangker dapat bertahan hidup dengan memperhatikan modal sosial.

\section{Tujuan Penelitian}

Untuk mendeskripsikan bagaimana para buruh tani di Desa Kopiwangker dapat bertahan hidup (Survive) berdasarkan Modal Sosial (kepercayaan, norma, dan jaringan) sebagai strateginya

\section{Manfaat Penelitian}

Manfaat dari penulisan ini adalah sebagai sumber ilmu pengetahuan tentang modal sosial sebagai strategi bertahan hidup buruh tani. Diharapkan kepada para pembaca untuk mendapat pengetahuan tentang modal sosial sebagai strategi bertahan hidup buruh tani. Penulisan ini juga diharapkan dapat menjadi bahan studi referensi untuk penulis-penulis selanjutnya dan referensi dalam melaksanakan suatu penelitian yang menyangkut penulisan ini.

\section{METODOLOGI PENELITIAN}

\section{Waktu dan Tempat Penelitian}

Penelitian ini dilaksanakan selama 5 bulan yaitu dari bulan Februari sampai dengan bulan Juni tahun 2016 dan mengambil lokasi di Desa Kopiwangker, Kecamatan Langowan Barat.

\section{Metode Pengumpulan Data}

Data yang digunakan dalam penelitian ini menggunakan data primer dan data sekunder, dimana data primer diperoleh dari wawancara secara langsung dengan hukum tua (kepala desa), aparat desa, key person di desa, dan dengan masyarakat yang khususnya buruh tani, dan didukung dengan observasi dan kuestioner.

Data sekunder di dapat dari instansiinstansi yang terkait dan memiliki data pendukung untuk penelitian ini, yaitu Badan Pusat Statistik Provinsi Sulawesi Utara.

\section{Metode Pengambilan Sampel}

Metode pengambilan sampel yang digunakan adalah "purposive sampling". Purposive sampling adalah teknik pengambilan sampel dengan cara mencampur subjek-subjek 
tanpa mempertimbangkan tingkatan-tingkatan dalam populasi (Arikunto, 2010). Purposive sampling termasuk dalam sampling nonprobabilitas dimana semua populasi tidak memiliki peluang atau kesempatan yang sama untuk dipilih menjadi sampel atau mewakili populasi, dan sampel diambil hanya berdasarkan tujuan penelitian.

Objek dalam penelitian ini adalah para buruh tani yang ada di Desa Kopiwangker, dan jumlah responden yang akan digunakan dalam penelitian ini adalah 30 responden yang tersebar pada 4 jaga/dusun. Berdasarkan wawancara yang dilakukan pada saat pra-survey dengan hukum tua, jumlah keseluruhan penduduk yang bermata pencaharian sebagai petani adalah $80 \%$ dari keseluruhan jumlah populasi Desa Kopiwangker atau sekitar 830 orang, hanya saja untuk jumlah buruh tani secara tepat belum diketahui. Hukum Tua hanya berkata bahwa hampir sebagian besar petani di Desa Kopiwangker berstatus sebagai buruh tani.

\section{Konsepsi Pengukuran Variabel}

Variabel yang akan digunakan pada penelitian ini adalah:

a. Karakteristik Petani:

1. Umur: Usia dari buruh tani dalam satuan Tahun.

2. Pendapatan: Pendapatan yang buruh tani dapat dari hasil mengelola ladang orang lain dalam satuan Rp/Bulan.

3. Pendidikan: Tingkat latar belakang pendidikan yang ditempuh buruh tani sampai mana (tidak sekolah, SD, SMP, SMA, Diploma, Sarjana)

b. Elemen-elemen Modal Sosial:

1. Kepercayaan (Trust): Kepercayaan, yaitu harapan yang tumbuh di dalam sebuah masyarakat yang ditunjukkan oleh adanya perilaku jujur, teratur, dan kerjasama berdasarkan norma-norma yang dianut bersama. Dalam kepercayaan perlu adanya kejujuran, komitmen untuk rasa saling percaya, keterbukaan, dan konsistensi untuk mendukung terbentuknya rasa saling percaya. Kepercayaan di ukur dengan dapat dipercaya atau tidaknya responden oleh orang lain.

2. Norma (Norms): Norma merupakan tata tertib, aturan, nilai, dan harapan yang mengatur dan mengontrol segala keadaan yang ada dan terjadi di suatu daerah/lingkungan.

Dalam kehidupan bermasyarakat biasanya tiap individu memiliki kepentingan masing-masing, maka itu perlu adanya norma untuk mengatur setiap kepentingan-kepentingan individu agar tidak terjadi kesenjangan sosial. Di dalam norma ada tata tertib dan aturan yang berlaku di dalam suatu lingkungan atau komunitas, ketika norma tidak berjalan maka tidak ada keteraturan. Norma di ukur dengan setuju atau tidaknya responden untuk mematuhi norma yang ada di desa.

3. Jaringan (Network): Asosiasi atau kelompok yang awalnya dimulai dari individu atau organisasi yang terbentuk karena hubungan-hubungan dan fenomena interaksi sosial yang terjadi di masyarakat.

Inti dari suatu jaringan sosial adalah kemampuan untuk membangun interaksi dan koneksi antar semua individu, jika tidak ada interaksi dan koneksi maka jaringan tidak bisa tercipta. Seperti bahasa, ketika kita pergi ke suatu daerah dan kita tidak tahu bahasa daerah tersebut, maka kita tidak bisa berkomunikasi dan berinteraksi dengan orang-orang daerah tersebut, maka tidak tercipta jaringan sosial. Jaringan di ukur dengan harmonis atau tidaknya hubungan responden dengan warga sekitar.

c. Strategi Bertahan Hidup menurut Scott:

1. Mengurangi pengeluaran untuk membeli makanan dan mengubah pola makan.

2. Menggunakan alternatif subsisten, dan bekerja sampingan; strategi bisa melibatkan semua anggota keluarga untuk bekerja, terutama istri.

3. Meminta bantuan jaringan sosial (saudara, kerabat, tetangga, dll), atau untuk petani bisa memanfaatkan hubungan dengan para Patronnya.

\section{Metode Analisis Data}

Teknik analisis data yang digunakan dalam penelitian ini adalah analisis deskriptif kualitatif yang di kuantitatifkan dengan menggunakan skala likert (likert scale). 
Analisis deskriptif bertujuan untuk memahami dengan lebih baik atau lebih dalam mengenai setiap permasalahan sosial dan interaksi manusia dan untuk mendapat jawaban yang lebih dalam mengenai suatu fenomena sosial. Metode kualitatif merupakan suatu prosedur penelitian yang menghasilkan data deskriptif berupa kata-kata tertulis atau lisan dari orangorang dan perilaku yang dapat diamati yang merupakan hasil dari observasi, dan wawancara secara mendalam.

Analisis deskriptif berusaha mencari pemecahan masalah dengan menganalisis dari gambaran hubungan sebab akibat dari faktorfaktor tertentu yang berhubungan dengan fenomena dari objek yang diteliti.

Skala likert (likert scale) memngkinkan responden untuk mengekspresikan intensitas perasaan mereka lebih luas. Hal ini dimungkinkan karena pertanyaan dalam skala likert memiliki jawaban yang berjenjang atau memiliki jawaban yang lebih banyak (Ridwan, 2012 dalam Umboh, 2014). Dalam penelitian ini skala likert digunakan untuk mengukur elemen-elemen modal sosial, yaitu kepercayaan, norma, dan jaringan. Dari semua

Cara perhitungan skor keseluruhan untuk mengetahui pengaruh modal sosial sebagai strategi bertahan hidup buruh tani:

Untuk:

$\mathrm{S} 3=3 \times 30 \times 15=1.350$

$\mathrm{S} 2=2 \times 30 \times 15=900$

$\mathrm{S} 1=1 \times 30 \times 15=450$

Jumlah skor ideal untuk keseluruhan pernyataan $=1.350$ (Tertinggi)

Jumlah skor Terendah $=450$

Dengan interpretasi nilai :

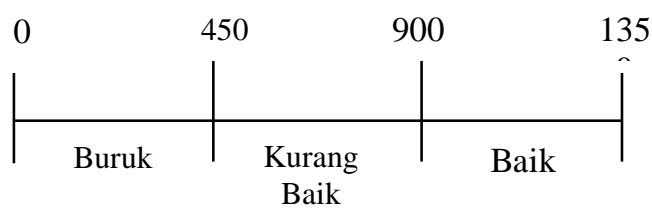

Analisis data yang digunakan merupakan analisis deskriptif yang diukur dengan skala likert dimana menurut Ridwan (2010) dalam Umboh (2014) adalah sebagai berikut:

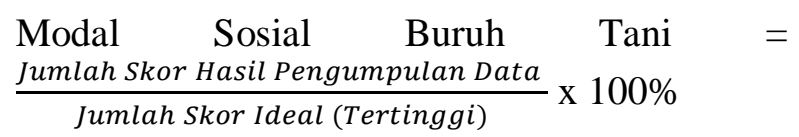

elemen yang ada disusun 15 pernyataan dengan total responden 30 orang.

Setiap jawaban dihubungkan dengan bentuk pernyataan yang diungkapkan dengan kata-kata berikut:

Dipercaya/ Setuju/ Harmonis: Skor : 3

Ragu-ragu

Skor : 2

Tidak Dipercaya/ Tidak Setuju/ Tidak Harmonis: Skor : 1

Dengan cara perhitungan skor masing-masing pertanyaan:

Jumlah Skor Tiap Kriterium = Capaian Skor X Jumlah Responden

Untuk:

$$
\begin{aligned}
& S 3=3 \times 30=90 \\
& S 2=2 \times 30=60 \\
& S 1=1 \times 30=30
\end{aligned}
$$

Jumlah skor ideal untuk setiap pernyataan (skor tertinggi) $=90$

Jumlah skor terendah $=30$

Dengan interpretasi nilai:

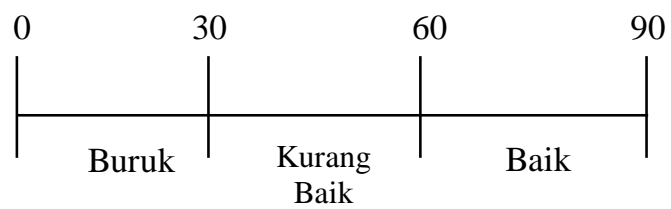

Jumlah Skor Seluruh Kriterium = Capaian Jumlah Skor X Jumlah Responden X Jumlah Pertanyaan

Dengan interpretasi nilai :

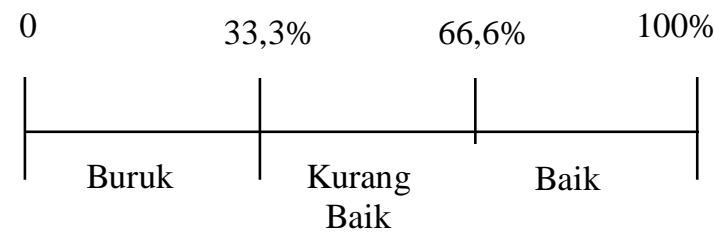

Keterangan Kriteria interpretasi skor:

Angka $0-33,3 \%=$ Buruk $(\mathrm{Bk})$

Angka 33,4\% - 66,6\% = Kurang Baik (KB)

Angka 66,7\% $-100 \%=$ Baik (B)

\section{HASIL DAN PEMBAHASAN}

\section{Deskripsi Wilayah Penelitian}

\section{Sejarah Desa}

Desa Kopiwangker berasal dari dua kata, yaitu kopi yang artinya tanaman kopi, dan Wangker yang artinya besar. Menurut para 
pendahulu bahwa daerah Kopiwangker dulunya merupakan perkebunan kopi yang sangat luas, dan kopi yang ditanam merupakan jenis kopi robusta.

Desa Kopiwangker dulunya merupakan bagian dari dua desa yang besar, yaitu Desa Kopiwangker dan Desa Lowian yang merupakan bagian dari Kecamatan Langowan. Demi kelancaran pelayanan kepada masyarakat di bidang Pemerintahan, Pembangunan, dan Kemasyarakatan, ditambah lagi jumlah penduduk yang terus bertambah, maka timbulah aspirasi dari seluruh elemen masyarakat dari dua desa tersebut membentuk satu desa yang baru. Melalui musyawarah yang dilakukan oleh para tokoh-tokoh desa, maka dicapai suatu kesepakatan bahwa terbentuklah satu desa, yaitu Desa Kopiwangker pada tanggal 21 Januari Tahun 2002. Desa Kopiwangker baru menjadi Desa Definitif pada tahun 2002 sampai dengan tahun 2007.

\section{Letak Wilayah}

Desa Kopiwangker merupakan bagian dari Kecamatan Langowan Barat, Kabupaten Minahasa, Provinsi Sulawesi Utara. Terdiri 4 dari Jaga/Dusun dengan batas wilayah:

Sebelah Utara: Desa Taraitak, Kec.Langowan Utara

Sebelah Timur: Desa Paslaten

Sebelah Selatan: Desa Walewangko dan Desa Lowian

Sebelah Barat : Desa Tumaratas dan Ampreng

\section{Luas Wilayah}

Luas wilayah Desa Kopiwangker adalah $62 \mathrm{Ha}$, yang membujur dari arah Timur ke Barat dan di bagian Barat merupakan daerah perkebunan milik masyarakat.

\section{Tata Guna Tanah Desa Kopiwangker}

Tanah Pemukiman : $20 \mathrm{Ha}$

Tanah Pertanian (Sawah): $20 \mathrm{Ha}$

Tanah Perkebunan $\quad: 20 \mathrm{Ha}$

Lain-lain $\quad: 2 \mathrm{Ha}$

\section{Keadaan Sosial}

\section{Jumlah Penduduk}

Jumlah Penduduk : 1043

Jiwa

- Laki-laki : 544 Jiwa

- Perempuan : 499 Jiwa

Jumlah Kepala Keluarga: 342

KK

\section{Kesejahteraan Sosial}

Jumlah Keluarga Pra-Sejahtera: 154 KK

Jumlah Keluarga Sejahtera : 45 KK

Jumlah Keluarga Miskin : 143 KK

\section{Karakteristik Responden}

\section{Umur Responden}

Tingkat umur mempengaruhi kemampuan seseorang dalam melakukan aktivitas maupun konsep berpikir. Responden yang berumur muda pasti memiliki kondisi fisik lebih kuat dibandingkan dengan responden yang berumur tua. Komposisi umur responden dalam penelitian ini disajikan pada Tabel 3.

Tabel 3. Jumlah Responden Berdasarkan Tingkat Umur

\begin{tabular}{llll}
\hline No. & $\begin{array}{l}\text { Umur } \\
\text { (Tahun) }\end{array}$ & $\begin{array}{l}\text { Jumlah } \\
\text { Responden } \\
(\text { Orang) }\end{array}$ & $\begin{array}{l}\text { Persentas } \\
\mathbf{e} \\
(\%)\end{array}$ \\
\hline 1. & $17-27$ & 0 & 0 \\
2. & $28-38$ & 5 & 16,66 \\
3. & $39-49$ & 7 & 23,33 \\
4. & $50-60$ & 11 & 36,66 \\
5. & $61>$ & 7 & 23,33 \\
\hline \multicolumn{2}{l}{ Jumlah } & 30 & 100 \\
\hline
\end{tabular}

Sumber : Data Primer, 2016. Diolah

Tabel 3 menunjukan bahwa jumlah responden terbanyak berada pada interval umur 50-60 tahun, dan selanjutnya pada interval umur 39-49 tahun dan 61> tahun, dan yang paling sedikit responden yang berada pada interval umur 28-38 tahun. Sedangkan interval umur 1727 tahun tidak ada. 


\section{Tingkat Pendidikan Responden}

Tingkah laku individu atau seseorang dapat dipengaruhi oleh pendidikan yang telah dicapai. Begitu juga pada buruh tani, tingkat pendidikan akan mempengaruhi sikap dan tingkah laku, dan juga cara bertahan hidup para buruh tani dan keluarganya.

Tabel 4. Jumlah Responden Menurut Tingkat Pendidikan Formal

\begin{tabular}{llll}
\hline No & $\begin{array}{l}\text { Tingkat } \\
\text { Pendidikan }\end{array}$ & $\begin{array}{l}\text { Jumlah } \\
\text { Responden } \\
\text { (Orang) }\end{array}$ & $\begin{array}{l}\text { Persentas } \\
\text { e } \\
(\%)\end{array}$ \\
\hline 1. & SD/SR & 23 & 76,66 \\
2. & SMP & 4 & 13,33 \\
3. & SMA/SMK & 3 & 10,00 \\
4. & $\begin{array}{l}\text { Perguruan } \\
\text { Tinggi }\end{array}$ & 0 & 0 \\
\hline Jumlah & 30 & 100 \\
\hline
\end{tabular}

Sumber : Data Primer, 2016. Diolah

Tabel 4 menunjukan tingkat pendidikan yang dimiliki para buruh tani. Tingkat pendidikan responden yang paling banyak, yaitu SD/SR (Sekolah Rakyat) sebanyak 23 orang $(76,66 \%)$, sedangkan tingkat SMP 4 orang $(13,33 \%)$, tingkat SMA/SMK 3 orang $(10,00 \%)$, dan pada tingkat Perguruan Tinggi tidak ada.

\section{Pekerjaan Responden}

Jenis pekerjaan sangat mempengaruhi kesejahteraan dan cara para buruh tani untuk bertahan hidup, dan bagi para buruh tani yang memiliki pekerjaan sampingan untuk dia dan keluarganya bertahan hidup. Ada beberapa buruh tani yang tidak hanya bekerja sebagai petani saja, tetapi memiliki pekerjaan di luar bertani yang dapat menambah perekonomian keluarganya.

Tabel 5 menunjukan bahwa dalam penelitian ini ada 6 orang buruh tani $(19,98 \%)$ yang memiliki pekerjaan diluar bertani, yaitu ada yang bekerja sebagai perangkat desa, berdagang kecil-kecilan (membuka warung), tukang bangunan, pembuat batu bata, pedagang sayur, dan ojek. Dari 30 responden, 6 orang memiliki pekerjaan di luar bertani, ini merupakan salah satu cara untuk keluarga petani untuk bertahan hidup.
Tabel 5. Jumlah Responden yang Memiliki Pekerjaan Sampingan

\begin{tabular}{llll}
\hline No & $\begin{array}{l}\text { Jenis } \\
\text { Pekerjaan } \\
\text { Sampingan }\end{array}$ & $\begin{array}{l}\text { Jumlah } \\
\text { Responden } \\
\text { (Orang) }\end{array}$ & $\begin{array}{l}\text { Persentas } \\
\text { e }\end{array}$ \\
\hline 1. & $\begin{array}{l}\text { Perangkat } \\
\text { Desa }\end{array}$ & 1 & 3,33 \\
2. & $\begin{array}{l}\text { Berdagang } \\
\text { (Warung) }\end{array}$ & 1 & 3,33 \\
3. & $\begin{array}{l}\text { Tukang } \\
\text { Bangunan }\end{array}$ & 1 & 3,33 \\
4. & $\begin{array}{l}\text { Pembuat } \\
\text { Batu Bata }\end{array}$ & 1 & 3,33 \\
5. & $\begin{array}{l}\text { Pedagang } \\
\text { Sayur }\end{array}$ & 1 & 3,33 \\
6. & $\begin{array}{l}\text { Ojek } \\
\text { Jumlah }\end{array}$ & 1 & 3,33 \\
\hline
\end{tabular}

Sumber : Data Primer, 2016. Diolah

\section{Modal Sosial}

\section{Kepercayaan (Trust)}

\section{Dapat Dipercaya oleh Penduduk Desa}

Buruh tani sebagai warga desa bisa dipercaya oleh penduduk desa yang lain/ tetangga. Kepercayaan merupakan salah satu komponen modal sosial yang sangat menentukan apakah dalam satu komunitas bisa terjalin hubungan yang baik atau tidak. Pernyataan ini ingin melihat apakah responden yang dalam penelitian ini adalah buruh tani bisa dipercaya atau tidak oleh warga desa.

Tabel 6. Dapat Dipercaya oleh Penduduk Desa

\begin{tabular}{|c|c|c|c|c|}
\hline $\begin{array}{l}\text { Alter } \\
\text { natif } \\
\text { Jawa } \\
\text { ban } \\
\end{array}$ & $\begin{array}{l}\text { Alter } \\
\text { natif } \\
\text { Skor }\end{array}$ & $\begin{array}{l}\text { Jumlah } \\
\text { Respond } \\
\text { en } \\
\text { (Orang) } \\
\end{array}$ & $\begin{array}{l}\text { Perse } \\
\text { ntase } \\
\text { Respo } \\
\text { nden } \\
\end{array}$ & $\begin{array}{l}\text { Total } \\
\text { Skor } \\
(\%)\end{array}$ \\
\hline Setuju & 3 & 30 & 100 & 90 \\
\hline $\begin{array}{l}\text { Ragu- } \\
\text { ragu }\end{array}$ & 2 & - & - & - \\
\hline $\begin{array}{l}\text { Tidak } \\
\text { Setuju }\end{array}$ & 1 & - & - & - \\
\hline Total & & 30 & 100 & 90 \\
\hline
\end{tabular}

Sumber : Data Primer, 2016. Diolah 
Hasil penelitian ini menunjukan bahwa 100\% (30 orang) setuju bahwa mereka bisa dipercaya oleh warga desa/tetangga. Total skor yang diperoleh dari 30 responden pada indikator pernyataan 1 adalah sebesar 90 . Angka indeks modal sosial mengenai pernyataan 1 yaitu: 90/90x100\% $=100 \%$, sehingga interpretasi nilainya baik karena responden yang adalah buruh tani bisa dipercaya oleh warga lain/tetangga.

\section{Dapat Dipercaya Saat Dimintai Bantuan Orang Lain}

Dalam pernyataan ini ingin dilihat apakah para responden (buruh tani) bisa dipercaya ketika ada warga/tetangga yang ingin meminta bantuan kepada mereka. Meminta bantuan misalnya ketika saat ada acara di desa lalu ada warga yang memanggil responden untuk membantu untuk memasang tenda atau memasak di acara tersebut, dan contoh-contoh serupa. Ketika ada warga/tetangga yang meminta bantuan kepada responden maka ada rasa saling percaya.

\section{Tabel 7. Dapat Dipercaya Saat Dimintai} Bantuan Orang Lain

\begin{tabular}{|c|c|c|c|c|}
\hline $\begin{array}{l}\text { Alter } \\
\text { natif } \\
\text { Jawa } \\
\text { ban }\end{array}$ & $\begin{array}{l}\text { Alter } \\
\text { natif } \\
\text { Skor }\end{array}$ & $\begin{array}{l}\text { Jumlah } \\
\text { Respond } \\
\text { en } \\
\text { (Orang) }\end{array}$ & $\begin{array}{l}\text { Perse } \\
\text { ntase } \\
\text { Respo } \\
\text { nden }\end{array}$ & $\begin{array}{l}\text { Total } \\
\text { Skor } \\
(\%)\end{array}$ \\
\hline Setuju & 3 & 29 & 96,66 & 87 \\
\hline $\begin{array}{l}\text { Ragu- } \\
\text { ragu }\end{array}$ & 2 & 1 & 3,33 & 2 \\
\hline $\begin{array}{l}\text { Tidak } \\
\text { Setuju }\end{array}$ & 1 & - & - & - \\
\hline Total & & 30 & 100 & 89 \\
\hline
\end{tabular}

Sumber : Data Primer, 2016. Diolah

Hasil penelitian ini menunjukan bahwa 96,66\% (29 orang) setuju bahwa mereka sering dimintai bantuan oleh warga desa/tetangga. Sedangkan 3,33\% (1 orang) ragu-ragu bahwa mereka sering dimintai bantuan oleh warga desa/tetangga. Total skor yang diperoleh dari 30 responden pada indikator pernyataan 2 adalah sebesar 89. Angka indeks modal sosial mengenai pernyataan 2 yaitu: 89/90x100\% = $98,88 \%$, sehingga interpretasi nilainya baik karena responden yang adalah buruh tani bisa dipercaya oleh warga lain/tetangga untuk dimintai bantuan.

\section{Dapat Dipercaya Saat Ingin Meminjam Uang atau Barang}

Pernyataan ini ingin melihat sejauh mana responden (buruh tani) bisa dipercaya oleh warga/tetangga saat meminjam uang atau barang, barang bisa berupa alat-alat pertanian dan lainnya.

Tabel 8. Dapat Dipercaya Saat Ingin Meminjam Uang atau Barang

\begin{tabular}{lllll}
\hline $\begin{array}{l}\text { Alter } \\
\text { natif } \\
\text { Jawa } \\
\text { ban }\end{array}$ & $\begin{array}{l}\text { Alter } \\
\text { natif }\end{array}$ & $\begin{array}{l}\text { Sumlah } \\
\text { Respond } \\
\text { en } \\
\text { (Orang) }\end{array}$ & $\begin{array}{l}\text { Perse } \\
\text { ntase } \\
\text { Respo } \\
\text { nden }\end{array}$ & $\begin{array}{l}\text { Total } \\
\text { Skor } \\
(\%)\end{array}$ \\
\hline $\begin{array}{l}\text { Setuju } \\
\text { Ragu- }\end{array}$ & 3 & 29 & 96,66 & 87 \\
ragu & 2 & 1 & 3,33 & 2 \\
$\begin{array}{l}\text { Tidak } \\
\text { Setuju }\end{array}$ & 1 & - & - & - \\
\hline Total & & 30 & 100 & 89 \\
\hline
\end{tabular}

Sumber : Data Primer, 2016. Diolah

Hasil penelitian ini menunjukan bahwa $96,66 \%$ (29 orang) setuju bahwa mereka bisa dipercaya saat ingin meminjam uang atau barang kepada warga desa/tetangga. Sedangkan $3,33 \%$ (1 orang) menjawab ragu-ragu bahwa mereka bisa dipercaya saat ingin meminjam uang atau barang kepada warga desa/tetangga. Total skor yang diperoleh dari 30 responden pada indikator pernyataan 3 adalah sebesar 89 . Angka indeks modal sosial mengenai pernyataan 3 yaitu: $89 / 90 \times 100 \%=98,88 \%$, sehingga interpretasi nilainya baik karena responden yang adalah buruh tani bisa dipercaya oleh warga lain/tetangga saat ingin meminjam uang atau barang.

\section{Dapat Dipercaya oleh Pemilik Lahan (Patron)}

Dalam profesi sebagai buruh tani, responden bisa dipercaya oleh pemilik lahan (patron) untuk menjalankan tugasnya sebaik mungkin. Pernyataan ini ingin melihat apakah responden dan patronnya memiliki rasa saling percaya yang baik. Ketika buruh tani dan pemilik lahan memiliki rasa saling percaya maka modal sosial bisa tercipta. 
Tabel 9. Dapat Dipercaya oleh Pemilik Lahan (Patron)

\begin{tabular}{lllll}
\hline $\begin{array}{l}\text { Altern } \\
\text { atif } \\
\text { Jawab } \\
\text { an }\end{array}$ & $\begin{array}{l}\text { Altern } \\
\text { atif } \\
\text { Skor }\end{array}$ & $\begin{array}{l}\text { Jumlah } \\
\text { Responde } \\
\text { n } \\
\text { (Orang) }\end{array}$ & $\begin{array}{l}\text { Perse } \\
\text { ntase } \\
\text { Respo } \\
\text { nden }\end{array}$ & $\begin{array}{l}\text { Total } \\
\text { Skor } \\
(\%)\end{array}$ \\
\hline $\begin{array}{l}\text { Setuju } \\
\text { Ragu- }\end{array}$ & 3 & 30 & 100 & 90 \\
ragu & 2 & - & - & - \\
$\begin{array}{l}\text { Tidak } \\
\text { Setuju }\end{array}$ & 1 & - & - & - \\
\hline Total & & 30 & 100 & 90 \\
\hline
\end{tabular}

Sumber : Data Primer, 2016. Diolah

Hasil penelitian ini menunjukan bahwa 100\% (30 orang) setuju bahwa mereka sebagai buruh tani bisa dipercaya oleh pemilik lahan (patron). Total skor yang diperoleh dari 30 responden pada indikator pernyataan 4 adalah sebesar 133. Angka indeks modal sosial mengenai pernyataan 4 yaitu: 90/90x $100 \%=$ $100 \%$, sehingga interpretasi nilainya baik karena responden yang adalah buruh tani bisa dipercaya oleh pemilik lahan (patron).

Tabel 10. Dalam Kegiatan Umum atau Kelompok di Desa Ada Rasa Saling Percaya di Antara Semua Warga

\begin{tabular}{lllll}
\hline $\begin{array}{l}\text { Alterna } \\
\text { tif } \\
\text { Jawaba } \\
\text { n }\end{array}$ & $\begin{array}{l}\text { Alterna } \\
\text { tif } \\
\text { Skor }\end{array}$ & $\begin{array}{l}\text { Jumlah } \\
\text { Responden } \\
\text { (Orang) }\end{array}$ & $\begin{array}{l}\text { Persent } \\
\text { ase } \\
\text { Respon } \\
\text { den }\end{array}$ & $\begin{array}{l}\text { Total } \\
\text { Skor } \\
(\%)\end{array}$ \\
\hline $\begin{array}{l}\text { Setuju } \\
\text { Ragu- } \\
\text { ragu }\end{array}$ & 3 & 30 & 100 & 90 \\
$\begin{array}{l}\text { Tidak } \\
\text { Setuju }\end{array}$ & 1 & - & - & - \\
\hline Total & & - & - & - \\
\hline
\end{tabular}

Sumber : Data Primer, 2016. Diolah
Responden yang adalah buruh tani di desa sering ikut berpartisipasi atau bergabung dengan kegiatan-kegiatan umum atau kelompok organisasi yang ada di desa, seperti ibadah, arisan, kelompok tani, dan lainnya; dan dalam kegiatan-kegiatan tersebut ada rasa saling percaya antara responden (buruh tani) dengan warga, begitu juga sebaliknya.

\section{Dalam Kegiatan Umum atau Kelompok di Desa Ada Rasa Saling Percaya di Antara Semua Warga}

Hasil penelitian ini menunjukan bahwa 100\% (30 orang) setuju bahwa dalam kegiatankegiatan umum atau kelompok di desa ada rasa saling percaya antara responden (buruh tani) dan warga. Total skor yang diperoleh dari 30 responden pada indikator pernyataan 5 adalah sebesar 90. Angka indeks modal sosial mengenai pernyataan 5 yaitu: 90/90x $100 \%=$ $100 \%$, sehingga interpretasi nilainya baik.

Tabel 11 menunjukan bahwa terdapat 5 indikator modal sosial buruh tani yang diukur dari segi Kepercayaan (Trust) dimana pernyataan 1,4, dan 5 adalah indeks modal sosial tertinggi, yaitu $100 \%$ dengan interpretasi sangat baik. Sedangkan pernyataan 2 , dan 3 mendapat indeks modal sosial $98,88 \%$. Semuanya mendapat interpretasi tinggi karena diatas $66,6 \%$

Tabel 11. Rekapitulasi Skor Indeks Modal Sosial dan Interpretasi Modal Sosial Buruh Tani dari Kepercayaan (Trust)

\begin{tabular}{lllll}
\hline No & Pernyataan & $\begin{array}{l}\text { Total } \\
\text { Skor }\end{array}$ & $\begin{array}{l}\text { Indeks } \\
\text { Sikap } \\
(\%)\end{array}$ & $\begin{array}{l}\text { Inter } \\
\text { preta } \\
\text { si }\end{array}$ \\
\hline 1. & Dapat Dipercaya oleh Penduduk Desa & 90 & 100 & Baik \\
2. & Dapat Dipercaya Saat Dimintai Bantuan Orang Lain & 89 & 98,88 & Baik \\
3. & Dapat Dipercaya Saat Ingin Meminjam Uang atau Barang & 89 & 98,88 & Baik \\
4. & Dapat Dipercaya oleh Pemilik Lahan (Patron) & 90 & 100 & Baik \\
5. & Dalam Kegiatan Umum atau Kelompok di Desa Ada Rasa & 90 & 100 & Baik \\
& Saling Percaya di Antara Semua Warga & & &
\end{tabular}




\section{Norma (Norms)}

\section{Patuh Terhadap Aturan/Tata Tertib yang Berlaku}

Norma merupakan salah satu komponen modal sosial yang harus diperhatikan jika ingin melihat apakah suatu hubungan bisa tercipta dengan baik atau tidak dalam suatu komunitas atau kelompok masyarakat. Ketika semua orang dalam satu komunitas atau kelompok masyarakat mematuhi setiap aturan/tata tertib yang berlaku di dalam komunitas tersebut maka akan tercipta hubungan yang baik diantara semua individu di dalamnya.

Dalam pernyataan tentang norma berikut ini ingin melihat apakah responden yang dalam penelitian ini adalah buruh tani dan juga sebagai warga desa mematuhi aturan/tata tertib yang berlaku di desa, seperti dengan tidak membuat keributan di desa, dan sebagainya. Hal ini ditunjukan pada Tabel 12.

\begin{tabular}{lllll}
\multicolumn{2}{c}{ Tabel 12. Patuh Terhadap Aturan/Tata Tertib yang Berlaku } \\
\hline $\begin{array}{l}\text { Alternatif } \\
\text { Jawaban }\end{array}$ & $\begin{array}{l}\text { Alternati } \\
\text { f } \\
\text { Skor }\end{array}$ & $\begin{array}{l}\text { Jumlah } \\
\text { Responden } \\
\text { (Orang) }\end{array}$ & $\begin{array}{l}\text { Persenta } \\
\text { se } \\
\text { Respond } \\
\text { en }\end{array}$ & $\begin{array}{l}\text { Total } \\
\text { Skor } \\
(\%)\end{array}$ \\
\hline Setuju & 3 & 30 & 100 & 90 \\
Ragu-ragu & 2 & - & - & - \\
Tidak & 1 & - & - & - \\
Setuju & & 30 & 100 & 90 \\
\hline Total & \multicolumn{3}{l}{}
\end{tabular}

Total
Sumber : Data Primer, 2016. Diolah

Hasil penelitian ini menunjukan bahwa $100 \%$ (30 orang) setuju bahwa mereka mematuhi aturan/tata tertib yang berlaku di desa. Total skor yang diperoleh dari 30 responden pada indikator pernyataan 6 adalah sebesar 90. Angka indeks modal sosial mengenai pernyataan 6 yaitu: 90/90x100\% = $100 \%$, sehingga interpretasi nilainya baik karena responden merasa bahwa mereka mematuhi aturan/tata tertib di desa.

\section{Perlu Ada Peraturan/Tata Tertib di Desa}

Melalui pernyataan ini ingin dilihat apakah responden merasa bahwa perlu ada aturan/tata tertib atau tidak di desa untuk membuat desa menjadi rapih dan tertib, dan bisa mengurangi masalah-masalah atau kesenjangan sosial yang bisa terjadi kapan saja di desa.
Tabel 13. Perlu Ada Peraturan/Tata Tertib di Desa

\begin{tabular}{|c|c|c|c|c|}
\hline $\begin{array}{l}\text { Alter } \\
\text { natif } \\
\text { Jawa } \\
\text { ban }\end{array}$ & $\begin{array}{l}\text { Alter } \\
\text { natif } \\
\text { Skor }\end{array}$ & $\begin{array}{l}\text { Jumlah } \\
\text { Respond } \\
\text { en } \\
\text { (Orang) }\end{array}$ & $\begin{array}{l}\text { Perse } \\
\text { ntase } \\
\text { Respo } \\
\text { nden } \\
\end{array}$ & $\begin{array}{l}\text { Total } \\
\text { Skor } \\
(\%)\end{array}$ \\
\hline Setuju & 3 & 29 & 96,66 & 87 \\
\hline $\begin{array}{l}\text { Ragu- } \\
\text { ragu }\end{array}$ & 2 & 1 & 3,33 & 2 \\
\hline $\begin{array}{l}\text { Tidak } \\
\text { Setuju }\end{array}$ & 1 & - & - & - \\
\hline Total & & 30 & 100 & 89 \\
\hline
\end{tabular}

Sumber : Data Primer, 2016. Diolah

Hasil penelitian ini menunjukan bahwa 96,66\% (29 orang) setuju bahwa perlu adanya peraturan/tata tertib di desa. Sedangkan 3,33\% (1 orang) ragu-ragu bahwa perlu adanya peraturan/tata tertib di desa. Total skor yang diperoleh dari 30 responden pada indikator pernyataan 7 adalah sebesar 89. Angka indeks modal sosial mengenai pernyataan 7 yaitu: $89 / 90 \times 100 \%=98,88 \%$, sehingga interpretasi nilainya baik karena responden merasa perlu ada aturan/tata tertib di desa.

\section{Mematuhi Syarat yang Ditentukan Bersama Pemilik Lahan}

Buruh tani bisa menjalin hubungan yang baik dengan pemilik lahan (patron) ketika dia bisa mematuhi setiap syarat atau kesepakatan yang telah dibuat bersama pemilik lahan. Kesepakatan yang telah dibuat menjadi norma dan aturan bagi buruh tani agar bisa bekerja sesuai yang diharapkan pemilik lahan

Tabel 14. Mematuhi Syarat yang Ditentukan Bersama Pemilik Lahan

\begin{tabular}{|c|c|c|c|c|}
\hline $\begin{array}{l}\text { Altern } \\
\text { atif } \\
\text { Jawab } \\
\text { an }\end{array}$ & $\begin{array}{l}\text { Altern } \\
\text { atif } \\
\text { Skor }\end{array}$ & $\begin{array}{l}\text { Jumlah } \\
\text { Responde } \\
\text { n } \\
\text { (Orang) }\end{array}$ & $\begin{array}{l}\text { Persen } \\
\text { tase } \\
\text { Respon } \\
\text { den }\end{array}$ & $\begin{array}{l}\text { Total } \\
\text { Skor } \\
(\%)\end{array}$ \\
\hline Setuju & 3 & 30 & 100 & 90 \\
\hline $\begin{array}{l}\text { Ragu- } \\
\text { ragu }\end{array}$ & 2 & - & - & - \\
\hline $\begin{array}{l}\text { Tidak } \\
\text { Setuju }\end{array}$ & 1 & - & - & - \\
\hline Total & & 30 & 100 & 90 \\
\hline
\end{tabular}

Sumber : Data Primer, 2016. Diolah

Hasil penelitian ini menunjukan bahwa $100 \%$ (30 orang) setuju bahwa sebagai buruh tani mereka mematuhi syarat dan kesepakatan yang ditentukan bersama pemilik lahan. Total skor yang diperoleh dari 30 responden pada indikator 
pernyataan 8 adalah sebesar 90. Angka indeks modal sosial mengenai pernyataan 8 yaitu: $90 / 90 \times 100 \%=88 \%$, sehingga interpretasi nilainya baik.

\section{Pemilik Lahan (Patron) Mematuhi Syarat yang Telah Ditentukan}

Pemilik lahan (patron) harus bisa dipercaya oleh para buruh tani, misalkan dalam hal kesepakatan sebelum buruh tani bekerja di lahannya. Ketika buruh tani mematuhi kesepakatan yang telah dibuat, maka pemilik lahan juga harus bisa mematuhinya, dengan begitu bisa menjalin hubungan yang baik dan rasa percaya yang kuat antara buruh tani dan pemilik lahan.

\begin{tabular}{|c|c|c|c|c|}
\hline $\begin{array}{l}\text { Altern } \\
\text { atif } \\
\text { Jawab } \\
\text { an }\end{array}$ & $\begin{array}{l}\text { Altern } \\
\text { atif } \\
\text { Skor }\end{array}$ & $\begin{array}{l}\text { Jumlah } \\
\text { Responde } \\
\text { n } \\
\text { (Orang) }\end{array}$ & $\begin{array}{l}\text { Perse } \\
\text { ntase } \\
\text { Respo } \\
\text { nden }\end{array}$ & $\begin{array}{l}\text { Total } \\
\text { Skor } \\
(\%)\end{array}$ \\
\hline Setuju & 3 & 30 & 100 & 90 \\
\hline $\begin{array}{l}\text { Ragu- } \\
\text { ragu }\end{array}$ & 2 & - & - & - \\
\hline $\begin{array}{l}\text { Tidak } \\
\text { Setuju }\end{array}$ & 1 & - & - & - \\
\hline Total & & 30 & 100 & 90 \\
\hline
\end{tabular}

Sumber : Data Primer, 2016. Diolah

Hasil penelitian ini menunjukan bahwa 100\% (30 orang) setuju bahwa pemilik lahan mematuhi kesepakatan dan syarat yang telah mereka buat. Total skor yang diperoleh dari 30 responden pada indikator pernyataan 9 adalah sebesar 90. Angka indeks modal sosial mengenai pernyataan 9 yaitu: $90 / 90 \times 100 \%=100 \%$, sehingga interpretasi nilainya baik karena buruh tani percaya bahwa pemilik lahan mematuhi kesepakatan dan syarat yang telah mereka buat.

\section{Andil Pemerintah Desa untuk Membuat Peraturan Kerja Bagi Buruh Tani}

Pemerintah desa (hukum tua) sebagai lembaga paling tinggi di desa perlu membuat peraturan kerja yang tetap bagi para buruh tani, dan peraturan ini bisa disepakati oleh para buruh tani dan pemilik lahan di desa. Peraturan itu berupa jumlah upah yang akan dibayarkan pemilik lahan (patron) kepada buruh tani.

Tabel 16. Andil Pemerintah Desa untuk Membuat Peraturan Kerja Bagi Buruh Tani

\begin{tabular}{lllll}
\hline $\begin{array}{l}\text { Alterna } \\
\text { tif }\end{array}$ & $\begin{array}{l}\text { Alterna } \\
\text { Jif } \\
\text { Jawaba } \\
\text { Skor }\end{array}$ & $\begin{array}{l}\text { Jumlah } \\
\text { Responden } \\
\text { (Orang) }\end{array}$ & $\begin{array}{l}\text { Persent } \\
\text { ase } \\
\text { Respon } \\
\text { den }\end{array}$ & $\begin{array}{l}\text { Total } \\
\text { Skor } \\
(\%)\end{array}$ \\
\hline $\begin{array}{l}\text { Setuju } \\
\text { Ragu- } \\
\text { ragu }\end{array}$ & 3 & 30 & 100 & 90 \\
$\begin{array}{l}\text { Tidak } \\
\text { Setuju }\end{array}$ & 1 & - & - & - \\
\hline Total & - & - & - \\
\hline Sumber : Data Primer, 2016. Diolah】 \\
\end{tabular}

Hasil penelitian ini menunjukan bahwa 100\% (30 orang) setuju bahwa perlu ada andil pemerintah desa untuk membuat peraturan kerja bagi buruh tani.. Total skor yang diperoleh dari 30 responden pada indikator pernyataan 10 adalah sebesar 90. Angka indeks modal sosial mengenai pernyataan 10 yaitu: 90/90x100\% $=100 \%$, sehingga interpretasi nilainya baik.

Tabel 17. Rekapitulasi Skor Indeks Modal Sosial dan Interpretasi Modal Sosial Buruh Tani dari Norma (Norms

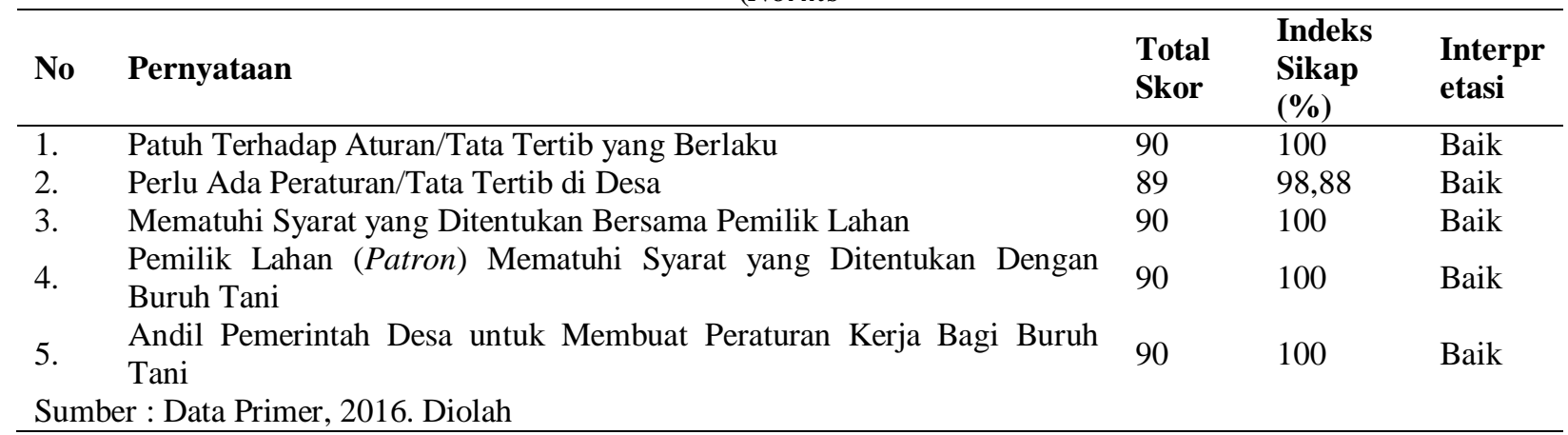

Tabel 17 menunjukan bahwa terdapat 5 indikator modal sosial buruh tani yang diukur dari segi Norma (Norms) dimana pernyataan 1 , 3,4 , dan 5 adalah indeks modal sosial tertinggi, 
yaitu $100 \%$ dengan interpretasi baik. Sedangkan pernyataan 2 mendapat indeks modal sosial $98,88 \%$. Semuanya mendapat interpretasi tinggi karena diatas $66,6 \%$.

\section{Jaringan (Network)}

\section{Hubungan dengan Penduduk Desa}

Dalam suatu komunitas atau lingkungan bermasyarakat perlu tercipta hubungan yang baik antara semua anggotanya, perlu ada jaringan yang menunjang kelangsungan hidup setiap masyarakat.

Buruh tani ketika ingin menunjang kelangsungan hidup dan keluarganya perlu menciptakan jaringan dengan anggota masyarakat desanya. Salah satu cara membangun jaringan adalah dengan membangun hubungan yang baik dengan semua warga desa. Tanpa hubungan yang baik maka buruh tani akan sulit untuk berkomunikasi dengan warga desa, bahkan untuk membangun jaringan menjadi sangat sulit. Jaringan merupakan komponen modal sosial yang menentukan apakah buruh tani bisa bertahan hidup dengan cara menjalin relasi dengan warga sekitarnya.

Tabel 18. Hubungan dengan Penduduk Desa

\begin{tabular}{lllll}
\hline $\begin{array}{l}\text { Alternatif } \\
\text { Jawaban }\end{array}$ & $\begin{array}{l}\text { Alternatif } \\
\text { Skor }\end{array}$ & $\begin{array}{l}\text { Jumlah } \\
\text { Responden } \\
\text { (Orang) }\end{array}$ & $\begin{array}{l}\text { Persentase } \\
\text { Responden }\end{array}$ & $\begin{array}{l}\text { Total } \\
\text { Skor } \\
(\%)\end{array}$ \\
\hline $\begin{array}{l}\text { Setuju } \\
\text { Ragu- } \\
\text { ragu }\end{array}$ & 3 & 30 & 100 & 90 \\
$\begin{array}{l}\text { Tidak } \\
\text { Setuju }\end{array}$ & 1 & - & - & - \\
\hline Total & & - & - & - \\
\hline Sumber & & 30 & 100 & 90 \\
\hline
\end{tabular}

Sumber : Data Primer, 2016. Diolah

Hasil penelitian ini menunjukan bahwa $100 \%$ (30 orang) setuju bahwa hubungan mereka dengan penduduk desa baik. Total skor yang diperoleh dari 30 responden pada indikator pernyataan 11 adalah sebesar 90 . Angka indeks modal sosial mengenai pernyataan 11 yaitu: 90/90x100\% $=100 \%$, sehingga interpretasi nilainya baik karena banyak dari responden (buruh tani) merasa bahwa hubungan mereka dengan tetangga dan warga desa lain baik.

\section{Hubungan dengan Orang di Luar Desa}

Dari indikator jaringan yang berikut ingin dilihat apakah responden yang dalam penelitian ini adalah buruh tani memiliki jaringan dengan orang dari luar desa, baik itu saudara/kerabat atau kenalan dari desa tetangga.

Tabel 19. Hubungan dengan Orang di Luar Desa

\begin{tabular}{lllll}
\hline $\begin{array}{l}\text { Alternatif } \\
\text { Jawaban }\end{array}$ & $\begin{array}{l}\text { Alternatif } \\
\text { Skor }\end{array}$ & $\begin{array}{l}\text { Jumlah } \\
\text { Responden } \\
\text { (Orang) }\end{array}$ & $\begin{array}{l}\text { Persentase } \\
\text { Responden }\end{array}$ & $\begin{array}{l}\text { Total } \\
\text { Skor } \\
(\%)\end{array}$ \\
\hline $\begin{array}{l}\text { Setuju } \\
\text { Ragu- }\end{array}$ & 3 & 30 & 100 & 90 \\
ragu & 2 & - & - & - \\
$\begin{array}{l}\text { Tidak } \\
\text { Setuju }\end{array}$ & 1 & - & - & - \\
\hline Total & & 30 & 100 & 90 \\
\hline
\end{tabular}

Sumber : Data Primer, 2016. Diolah

Hasil penelitian ini menunjukan bahwa $100 \%$ (30 orang) setuju bahwa hubungan mereka dengan orang luar desa baik dan mereka memiliki jaringan di luar desa. Total skor yang diperoleh dari 30 responden pada indikator pernyataan 12 adalah sebesar 90 . Angka indeks modal sosial mengenai pernyataan 12 yaitu: 90/90x100\% $=100 \%$, sehingga interpretasi nilainya baik karena banyak dari responden (buruh tani) merasa bahwa hubungan mereka dengan orang luar desa baik.

\section{Tabel 20. Hubungan dengan Pemilik} Lahan

\begin{tabular}{|c|c|c|c|c|}
\hline $\begin{array}{l}\text { Alter } \\
\text { natif } \\
\text { Jawa } \\
\text { ban }\end{array}$ & $\begin{array}{l}\text { Alter } \\
\text { natif } \\
\text { Skor }\end{array}$ & $\begin{array}{l}\text { Jumlah } \\
\text { Respond } \\
\text { en } \\
\text { (Orang) }\end{array}$ & $\begin{array}{l}\text { Perse } \\
\text { ntase } \\
\text { Respo } \\
\text { nden }\end{array}$ & $\begin{array}{l}\text { Total } \\
\text { Skor } \\
(\%)\end{array}$ \\
\hline Setuju & 3 & 30 & 100 & 90 \\
\hline $\begin{array}{l}\text { Ragu- } \\
\text { ragu }\end{array}$ & 2 & - & - & - \\
\hline $\begin{array}{l}\text { Tidak } \\
\text { Setuju }\end{array}$ & 1 & - & - & - \\
\hline Total & & 30 & 100 & 90 \\
\hline
\end{tabular}

Sumber : Data Primer, 2016. Diolah 
Tabel 21. Hubungan dengan Warga Lain dalam Kegiatan Umum yang Dilakukan di Desa

\begin{tabular}{lllll}
\hline $\begin{array}{l}\text { Alternatif } \\
\text { Jawaban }\end{array}$ & $\begin{array}{l}\text { Alternatif } \\
\text { Skor }\end{array}$ & $\begin{array}{l}\text { Jumlah } \\
\text { Responden } \\
\text { (Orang) }\end{array}$ & $\begin{array}{l}\text { Persentase } \\
\text { Responden }\end{array}$ & $\begin{array}{l}\text { Total Skor } \\
(\%)\end{array}$ \\
\hline Setuju & 3 & 30 & 100 & 90 \\
Ragu-ragu & 2 & - & - & - \\
Tidak Setuju & 1 & - & - & - \\
\hline Total & & 30 & 100 & 90 \\
\hline
\end{tabular}

Sumber : Data Primer, 2016. Diolah

Tabel 22. Ikut Membantu Jika Ada Tetangga atau Warga yang Sedang Memerlukan Bantuan, Seperti Memasang Tenda Jika Ada Acara, atau Memasak

\begin{tabular}{lllll}
\hline $\begin{array}{l}\text { Alternatif } \\
\text { Jawaban }\end{array}$ & $\begin{array}{l}\text { Alternatif } \\
\text { Skor }\end{array}$ & $\begin{array}{l}\text { Jumlah } \\
\text { Responden } \\
\text { (Orang) }\end{array}$ & $\begin{array}{l}\text { Persentase } \\
\text { Responden }\end{array}$ & $\begin{array}{l}\text { Total Skor } \\
(\%)\end{array}$ \\
\hline $\begin{array}{l}\text { Setuju } \\
\text { Ragu-ragu }\end{array}$ & 3 & 30 & 100 & 90 \\
Tidak Setuju & 2 & - & - & - \\
\hline Total & 1 & - & - & - \\
\hline Sumber & & 30 & 100 & 90 \\
\hline
\end{tabular}

Sumber : Data Primer, 2016. Diolah

Tabel 23. Rekapitulasi Skor Indeks Modal Sosial dan Interpretasi Modal sosial Buruh Tani dari Jaringan (Network)

\begin{tabular}{lllll}
\hline No & Pernyataan & $\begin{array}{l}\text { Total } \\
\text { Skor }\end{array}$ & $\begin{array}{l}\text { Indeks } \\
\text { Sikap } \\
(\boldsymbol{\%})\end{array}$ & $\begin{array}{l}\text { Interp } \\
\text { retasi }\end{array}$ \\
\hline 1. & Hubungan dengan Penduduk Desa & 90 & 100 & Baik \\
\hline 2. & Hubungan dengan Orang di Luar Desa & 90 & 100 & Baik \\
\hline 3. & Hubungan dengan Pemilik Lahan & 90 & 100 & Baik \\
\hline 4. & $\begin{array}{l}\text { Hubungan dengan Warga Lain Dalam Kegiatan Umum yang } \\
\text { Dilakukan di Desa }\end{array}$ & 90 & 100 & Baik \\
\hline & $\begin{array}{l}\text { Ikut Membantu Jika Ada Tetangga atau Warga yang Sedang } \\
\text { Memerlukan Bantuan, Seperti Memasang Tenda Jika Ada } \\
\text { Acara, atau Memasak } 90\end{array}$ & 100 & Baik
\end{tabular}

Sumber : Data Primer, 2016. Diolah

Hubungan dengan Pemilik Lahan

Responden yang adalah buruh tani harus bisa menjalin hubungan yang baik dengan pemilik lahan (patron), karena pada kenyataannya ada buruh tani yang memerlukan bantuan dan mereka meminta bantuan itu kepada pemilik lahan dimana dia bekerja. Jika tidak ada hubungan yang baik antara buruh tani dan pemilik lahan maka dia akan sulit untuk meminta bantuan kepada pemilik lahan (patron). Hasil penelitian ini menunjukan bahwa 100\% (30 orang) setuju bahwa hubungan mereka dengan pemilik lahan (patron) baik. Total skor yang diperoleh dari 30 responden pada indikator pernyataan 13 adalah sebesar 90. Angka indeks modal 
sosial mengenai pernyataan 13 yaitu: $90 / 90 \times 100 \%=100 \%$, sehingga interpretasi nilainya baik.

\section{Hubungan dengan Warga Lain dalam Kegiatan Umum yang Dilakukan di Desa}

Buruh tani yang adalah masyarakat desa menjalin hubungan yang baik dengan warga desa dengan cara mengikuti kegiatan-kegiatan umum yang dilakukan di desa, seperti arisan, ibadah, dan sebagainya; karena dalam kegiatan-kegiatan tersebut dapat membentuk keakraban yang baik diantara semua warga desa.

\section{Ikut Membantu Jika Ada Tetangga atau Warga yang Sedang Memerlukan Bantuan, Seperti Memasang Tenda Jika Ada Acara, atau Memasak}

Dalam indikator jaringan yang berikut ini ingin dilihat apakah responden sering membantu jika ada tetangga atau warga yang meminta bantuan, karena jika dia sering membantu warga sekitar artinya hubungan dia dengan warga sekitar baik dan ada rasa percaya warga sekitar terhadap dia. Jaringan yang baik bisa tercipta ketika ada rasa percaya antara masing-masing orang, begitu juga dalam kehidupan buruh tani. Ketika ada warga/tetangga yang sering memintai dia bantuan artinya warga/tetangga tersebut percaya kepada buruh tani. Hasil penelitian ini menunjukan bahwa 100\% (30 orang) setuju bahwa mereka sering ikut membantu jika ada tetangga atau warga yang sedang memerlukan bantuan. Total skor yang diperoleh dari 30 responden pada indikator pernyataan 15 adalah sebesar 90. Angka indeks modal sosial mengenai pernyataan 15 yaitu: 90/90x100\% = $100 \%$, sehingga interpretasi nilainya baik karena responden sering ikut membantu jika ada tetangga atau warga yang sedang memerlukan bantuan. Tabel 23 menunjukan bahwa terdapat 5 indikator modal sosial buruh tani yang diukur dari segi Jaringan (Network) dimana semua pernyataan mendapat angka indeks modal sosial tertinggi, yaitu $100 \%$ dengan interpretasi baik. Semuanya mendapat interpretasi tinggi karena diatas 66,6\%
Hasil penelitian ini menunjukan bahwa 100\% (30 orang) setuju bahwa dalam kegiatankegiatan umum yang dilakukan, seperti arisan, ibadah, dan lainnya, hubungan mereka dengan warga lain baik. Total skor yang diperoleh dari 30 responden pada indikator pernyataan 14 adalah sebesar 90. Angka indeks modal sosial mengenai pernyataan 14 yaitu: 90/90x100\% = $100 \%$, sehingga interpretasi nilainya baik karena responden dalam kegiatan-kegiatan umum yang dilakukan, seperti arisan, ibadah, dan lainnya, hubungan mereka dengan warga lain baik.

\section{Rekapitulasi Indeks Modal Sosial Buruh Tani Tiap Indikator dan Interpretasi Hasil}

Penelitian untuk mengukur modal sosial buruh tani terhadap cara mereka bertahan hidup yang diterapkan mengambil 15 indikator sebagai tolak ukur dalam penelitian ini, dimana masing-masing terbagi dalam 3 (tiga) bagian yaitu Kepercayaan (Trust), Norma (Norms), dan Jaringan (Network).

Hasil penelitian menunjukkan bahwa semua indikator mendapatkan skor pada indeks yang baik (66,7\%-100\%). Hal ini menunjukan bahwa pengaruh modal sosial (kepercayaan, norma, dan jaringan) tergolong baik dalam menjadi strategi bertahan hidup buruh tani di Desa Kopiwangker, Kecamatan Langowan Barat. Namun dari ketiga unsur, yang memiliki pengaruh tertinggi adalah jaringan dengan skor 450, karena semua responden mampu membangun jaringan yang baik dengan semua warga desa.

Untuk mengetahui pengaruh modal sosial sebagai strategi bertahan hidup buruh tani, maka perlu dihitung jumlah keseluruhan skor pada setiap kriterium, dimana sesuai hasil penelitian ini skor mencapai 1.347. Pada penelitian ini jumlah skor ideal (tertinggi), yaitu 1.350, dan jumlah skor terendah, yaitu 450. Berdasarkan data yang dihimpun dari sebanyak 15 indikator pernyataan yang diajukan kepada 30 responden, maka diperoleh total skor 1.347, dengan letak skor indeks ditentukan berdasarkan skala likert berikut: 


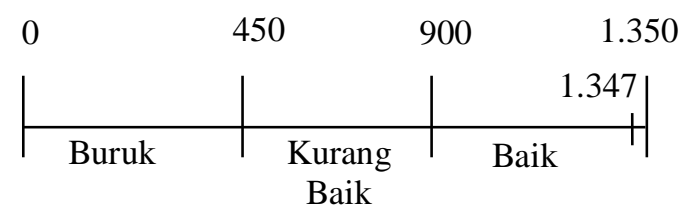

Secara presentase, angka indeks modal sosial sebagai strategi bertahan hidup buruh tani terletak pada:

$$
\begin{gathered}
\text { Modal } \begin{array}{l}
\text { Sosial } \\
\text { Jumlah Skor Hasil Pengumpulan Data }
\end{array} \\
\begin{array}{c}
\text { Jumlah Skor Ideal (Tertinggi) } \\
=\frac{1347}{1350} \times 100 \%=99,77 \%
\end{array}
\end{gathered}
$$

Dengan interpretasi nilai :

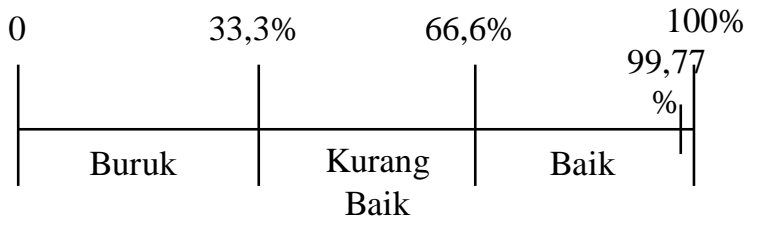

Berdasarkan hasil analisis menggunakan skala likert, maka dapat diketahui bahwa angka indeks modal sosial sebagai strategi bertahan hidup buruh tani berada pada titik $99,77 \%$ dan tergolong baik. Namun, setelah di adakan crosscheck kembali di Desa Kopiwangker, ternyata terdapat kontradiksi antara data yang di dapat dengan informasi yang di dapat dari beberapa informan. Menurut beberapa informan bahwa pernah terjadi masalah yang melibatkan buruh tani dan patron yang mengakibatkan keributan antara buruh tani dan patron, dan patron sampai tidak memperkerjakan buruh tani tersebut lagi di lahan miliknya. Masalah tersebut tidak terjadi pada semua buruh tani, hanya pada sebagian kecil buruh tani saja.

\section{Modal Sosial di Desa}

Modal sosial yang ada pada masyarakat di Desa Kopiwangker baik dan kuat. Bukan hanya pada buruh tani tapi pada masyarakat umum juga sangat kuat ikatannya. Rasa percaya antara satu dengan yang lain terjalin dengan erat, bahkan hampir tidak ada rasa curiga diantara setiap orang. Norma dan aturan-aturan yang ada di desa bisa ditaati dengan baik sehingga keteraturan dan ketertiban di desa bisa tercipta. Jaringan dan hubungan tiap anggota masyarakatnya sangat kuat, bahkan sebagian besar penduduknya ada yang memang masih bersaudara (keluaga), jadi kekerabatannya bisa terjalin. Rasa tolong menolong diantara setiap warga sangat tinggi. Ada tiga kepala keluarga yang bisa tinggal dalam satu rumah tanpa ada keributan, menandakan bahwa modal sosial masih kuat.

Menurut hukum tua desa dan beberapa responden mengatakan bahwa "hukum kasih" sangat kuat di Desa Kopiwangker sehingga modal sosial di Desa Kopiwangker sudah memang ada dari dulu, kalau ada masalah tidak akan sampai lama masalah itu selesai. Bahkan jika ada tetangga yang membutuhkan sayuran atau rempah-rempah tapi tidak punya, dia bisa langsung memintanya kepada tetangga atau masyarakat yang menanam disekitar rumahnya.

Bagi para buruh tani yang adalah masyarakat desa, dengan keadaan modal sosial yang kuat di Desa Kopiwangker maka bisa membantunya untuk bertahan hidup. Untuk para buruh tani di Desa Kopiwangker sudah ada aturan tetap yang dibuat pemerintah desa bahwa upah per-hari untuk pria Rp.100.000 dan untuk wanita Rp.80.000; untuk jam kerja buruh tani yang telah ditentukan adalah jam 7 pagi sampai jam 5 sore, dan itu bisa diikuti oleh semua buruh tani. Hal ini menunjukkan bahwa modal sosial di Desa Kopiwangker memang sangat baik, bukan hanya pada buruh tani tapi pada seluruh masyarakat di Desa Kopiwangker. Sekalipun banyak dari buruh tani yang ekonominya rendah tapi tetap bisa bertahan hidup karena adanya modal sosial yang baik di Desa Kopiwangker.

\section{Strategi Bertahan Hidup}

Masyarakat di Desa Kopiwangker memang hampir sebagian besar bermata pencaharian sebagai petani, dari hasil wawancara dengan hukum tua ada sekitar $80 \%$ penduduk yang bekerja sebagai petani yang di dalamnya termasuk buruh tani. Menurut hasil survey bahwa sebagian besar penduduk berpendidikan SD atau Sekolah Rakyat dengan kondisi ekonomi banyak yang rendah. Tercatat bahwa di Desa Kopiwangker ada 143 keluarga 
miskin dan banyak dari keluarga tersebut yang bekerja sebagai petani.

Strategi bertahan hidup adalah cara untuk seseorang bisa bertahan dalam kondisi yang mengancam hidupnya, karena ketika hidup seseorang mulai terancam maka dia akan berpikir bagaimana agar dia tetap bisa bertahan hidup. Buruh tani memiliki strategi bertahan hidup untuk kelangsungan hidupnya dan keluarganya. Responden yang adalah buruh tani di Desa Kopiwangker memiliki strategi bertahan hidup, yaitu:

1. Mengubah pola makan: semua responden mengatakan bahwa mereka sehari makan 3 (tiga) kali, tapi terkadang ketika mereka tidak memiliki beras maka mereka menggantinya dengan ubi atau jagung sebagai makanan pokok. Untuk membeli bahan-bahan makanan seperti sayur dan lauk-pauk mereka katakan tidak tentu, tapi ada responden yang mengatakan bahwa jika memang butuh sayur atau rempahrempah, tinggal ambil di kebun dan sekitaran rumah, atau juga meminta pada tetangga.

2. Alternatif subsisten: tidak semua responden yang memiliki pekerjaan lain selain menjadi buruh tani. Dari 30 responden hanya 6 responden yang memiliki pekerjaan selain buruh tani, ada yang menjadi perangkat desa, berdagang (warung), tukang bangunan, pembuat batu bata, pedagang sayur, dan tukang ojek. Banyak dari responden yang menggunakan halaman/pekarangan rumahnya untuk menanam sayur atau rempah-rempah untuk digunakan sendiri.

3. Bantuan jaringan sosial: hampir semua responden yang memiliki kerabat/saudara/kenalan tinggal di Desa Kopiwangker, desa tetangga, dan juga di luar Langowan; sehingga jaringannya banyak jika dia butuh bantuan. Responden juga ada yang meminta bantuan kepada tetangga/warga desa dan pemilik lahan (patron) seperti jika butuh pinjaman uang atau barang (alat pertanian), hanya saja jarang yang butuh pinjaman uang.

\section{KESIMPULAN DAN SARAN}

\section{Kesimpulan}

Modal sosial mempengaruhi strategi bertahan hidup buruh tani di Desa Kopiwangker. Buruh tani bisa bertahan hidup dengan membangun nilai modal sosial yang baik di desa, dengan cara saling percaya antara semua warga desa, mematuhi aturan dan tata tertib yang ada di desa, dan menjalin hubungan yang baik diantara semua warga desa; yang pasti buruh tani harus punya hubungan yang baik dengan pemilik lahan dimana dia bekerja. Dari ketiga unsur modal sosial, yang memiliki pengaruh tertinggi bagi strategi bertahan hidup adalah jaringan.

Strategi bertahan hidup buruh tani juga dipengaruhi oleh cara mereka mengubah pola makan, pekerjaan lain selain buruh tani, dan memanfaatkan pekarangan rumah untuk menanam sayuran, buah-buahan, dan rempahrempah, dan jaringan sosial yang mereka miliki. Semakin baik modal sosial yang ada pada semua buruh tani maka semakin mudah strategi mereka untuk bertahan hidup.

\section{Saran}

Bagi para buruh tani agar dapat terus menjaga dan mempertahankan modal sosial yang sudah terjalin dengan baik, tidak hanya untuk sekedar bertahan hidup tapi untuk bisa memiliki hidup yang lebih baik.. Terus pertahankan rasa percaya diantara sesama warga desa, menaati norma dan aturan yang berlaku untuk ketertiban desa, dan mempererat hubungan dan jaringan diantara masing-masing orang.

\section{DAFTAR PUSTAKA}

Anam, Khoirul., 2013. Identifikasi Modal Sosial Dalam Kelompok Tani dan Implikasinya Terhadap Kesejahteraan Anggota Kelompok Tani (Studi Kasus pada Kelompok Tani Tebu Ali Wafa di Desa Rejoyoso Kecamatan Bantur Kabupaten Malang). Jurnal Ilmiah Universitas Brawijaya, Malang. 
Anwas, Oos M., kata pengantar Haryono Suyono., 2013. Pemberdayaan Masyarakat di Era Global. Penerbit ALFABETA, cv, Bandung.

Badan Kependudukan dan Keluarga Berencana, 2013. Profil Hasil Pendataan Keluarga Tahun 2012. Badan Kependudukan dan Keluarga Berencana Direktorat Pelaporan dan Statistik. Jakarta.

Badan Pusat Statistik, 2015. Statistik Daerah Provinsi Sulawesi Utara 2015. Katalog BPS: 1101002.71. BPS Provinsi Sulawesi Utara.

2015. Sulawesi Utara Dalam Angka 2015. Katalog BPS: 1102001.71. BPS Provinsi Sulawesi Utara.

2014. Statistik Potensi

Desa Provinsi Sulawesi Utara 2014. Katalog BPS: 1105014.71. BPS.

2014. Statistik Potensi Desa Kabupaten Minahasa 2014. Katalog BPS: 1105014.71. BPS Provinsi Sulawesi Utara.

Dari., Listyaningsih, 2015. Strategi Orang Tua Etnis Arab Dalam Membentuk Moral Anak Di Perkampungan Ampel Kota Surabaya. Kajian Moral dan Kewarganegaraan. Volume 01 Nomor 03 Tahun 2015.

Fiedhawatie, Shintya Dwi 2013. Maslow's Hierarchy of Needs Manifested By the Main Character in the Forrest Gump the Movie. Jurnal Universitas Brawijaya, Malang.

Faturochman, Marcelinus Molo, 1994. Karakteristik Rumah Tangga Miskin di Daerah Istimewa Yogyakarta. E-Jurnal. Di akses pada tanggal 11 Februari 2016.

Fauziah, Nurul, 2014. Peran Modal Sosial Dalam Kesejahteraan Ekonomi Rumah Tangga Petani. Laporan Studi Pustaka, Institut Pertanian Bogor.
Habdy Lubis, Rissalwan, 2012. Pemahaman Konsep Modal Sosial. Lembaga Kemitraan Pembangunan Sosial (LKPS).

http://www.artikelsiana.com/2014/10/pengertia n-norma-fungsi-norma-definisi.html. 4 Juni 2016

http://www.bkkbn-jatim.go.id/bkkbnjatim/html/indikasi.html. 19 Feb 2016

http://www.konsistensi.com/2013/04/teorisampel-dan-sampling-penelitian.html. 5 Juni 2016

http://rizka-meilinda-

fisip13.web.unair.ac.id/artikel detail$\underline{141511 .} 5$ Juni 2016

Kartono, Kartini., 2014. Patologi Sosial jilid 1. Edisi 2. Penerbit PT RajaGrafindo Persada, Jakarta.

kbbi.web.id/norma. 5 Juni 2016

Khotijah, Nugroho Hari Purnomo, 2014. Strategi Bertahan Hidup Penambang Belerang Di Desa Tamansari Kecamatan Licin Kabupaten Banyuwangi. Skripsi Universitas Negeri Surabaya.

Kumesan, Charles R. Ngangi, Mellisa L.G. Tarore, Paulus A. Pangemanan, 2015. Strategi Bertahan Hidup (Life Survival Strategy) Buruh Tani di Desa Tombatu Dua Utara Kecamatan Tombatu Utara. EJurnal. Di akses pada tanggal 11 Februari 2016.

Lusianti, Hesti, 2014. Studi Korelasi Pengetahuan dengan Sikap Petani Terhadap Lahan Pertanian Berkelanjutan di Kecamatan Kembaran Kabupaten Banyumas Jawa Tengah. Skripsi Universitas Muhamadiyah, Purwokerto.

Mariani, 2014. Modal Sosial Dan Dukungan Sosial Serta Dampaknya Terhadap Kesejahteraan Lanjut Usia (Kasus Pada Program Home Care Panti Sosial Tresna Werdha Gau Mabaji Gowa). Tesis Universitas Hasanudin, Makassar. 
Masik, Agustomi, 2005. Hubungan Modal Sosial dan Perencanaan. Jurnal Perencanaan Wilayah dan Kota, Volume 16/ No.3. Program Doktor Perencanaan Wilayah dan Kota Institut Tekonolgi Bandung.

Nugraha, Heri Surya, 2015. Strategi Bertahan Hidup Petani Di Kelurahan Made, Surabaya. Jurnal.

Primadona, 2008. Peran Penting Trust Sebagai Energi Pembangunan Masyarakat. Jurnal Ekonomi dan Bisnis Volume 3 No.1.

Pusat Data dan Sistem Informasi Pertanian, 2014. Statistik Lahan Pertanian Tahun 2009-2013. Penerbit: Pusat Data dan Sistem Informasi Pertanian Sekretariat Jenderal - Kementrian Pertanian 2014.

Qandhi, Fika Fatia, 2014. Peran Perempuan dalam Gerakan Petani Lahan Pasir Kulon Progo (Kasus Desa Bugel, Kecamatan Panjatan, Kabupaten Kulon Progo). Makalah Kolokium.

Rangkuti, Freddy, 2006. Analisis SWOT Teknik Teknik Membedah Kasus Bisnis (Reorientasi Konsep Perencanaan Strategis Untuk menghadapi Abad 21). Penerbit PT Gramedia Pustaka Utama, Jakarta. Google Books diakses pada tanggal 5 Juni 2016.

Sakina, Aulia Widya, 2011. Memahami Modal Sosial dalam Pengentasan Kemiskinan: Studi Kasus PNPM Mandiri Perkotaan di Kelurahan Muntilan dan Desa Gunungpring, Kabupaten Magelang. Skripsi Universitas Gadjah Mada, Yogyakarta.

Sembiring, Kristina, 2009. Kondisi Kehidupan Sosial Ekonomi Buruh Harian Lepas (Aron) di Kelurahan Padang Mas Kecamatan Kabanjahe Kabupaten Karo. Skripsi Universitas Sumatera Utara, Medan.
Septiadi, Muhammad, 2013. Pengaruh Ketimpangan Gender Terhadap Strategi Bertahan Hidup Rumah Tangga Buruh Tani Miskin Di Desa Cikarawang. Skripsi Institut Pertanian Bogor.

Setyawati, Tya, 2015. Modal Sosial Dalam Pengembangan Di Desa Wisata Tembi Kecamatan Sewon Kabupaten Bantul Daerah Istimewa Yogyakarta. Skripsi Universitas Negeri Yogyakarta.

skpd.batamkota.go.id. Di akses pada tanggal 14 Desember 2015.

Shabrina, Gina Nefstia, 2015. Hubungan Modal Sosial Terhadap Efektivitas Program Corporate Social Resposibility (CSR). Laporan Studi Pustaka, Institut Pertanian Bogor.

Subarkah, 2015. Strategi Pembelajaran Torseba Kuis Famili 30-2 Untuk Meningkatkan Standar Kompetensi Inflasi Siswa. Prosiding Seminar Nasional 9 Mei 2015, Universitas Negeri Surabaya.

Subejo, 2004. Peranan Social Capital Dalam Pembangunan Ekonomi: Suatu Pengantar untuk Studi Social Capital di Pedesaan Indonesia. Artikel dalam Jurnal Agro Ekonomi Vol.11. No.1 Juni 2004.

Suharto, Edi, 2002. Coping Strategies Dan Keberfungsian Sosial: Mengembangkan Pebdekatan Pekerjaan Sosial Dalam Mengkaji Dan Menangani Kemiskinan. Bahan seminar di Institut Pertanian Bogor. Di akses pada tanggal 5 Juni 2016, di www.policy.hu.

Sunarti., Ali Khomsan, ( _ _ ) Kesejahteraan Keluarga Petani Mengapa Sulit Diwujudkan?. Jurnal Institut Pertanian Bogor.

Suryadi, A Humam Hamid, Agussabti, 2013. Strategi Bertahan Hidup Petani Kopi Pasca Konflik (Studi Kasus di Kecamatan Kute Panang Kabupaten Aceh Tengah). E-Journal, Agrisep Vol (14) No.1, 2013. 
Tapi, Triman, 2014. Konstruksi Sosial Petani Dalam Pembentukan Kelompok Tani (Suatu Kajian Sosiologis Terhadap Kelompok Tani Penerima Bantuan Dana Pengembangan Usaha Agribisnis Perdesaan Di Kabupaten Manokwari, Papua Barat). Tesis Universitas Hasanudin, Makassar.

Trianto, Eko, 2013. Implementasi Manajemen Strategi di Madrasah Aliyah Negeri (MAN) Yogyakarta III Sinduadi, Mlati, Sleman, Yogyakarta. Skripsi Universitas Islam Negeri Sunan Kalijaga, Yogyakarta.

Ulinnuha, M Zulham, 2011. Strategi Peningkatan Produktivitas Petani Melalui Penguatan Modal Sosial (Studi Empiris di Kecamatan Guntur Kabupaten Demak). Skripsi Universitas Diponegoro, Semarang.
Umboh, Jennifer, 2014. Pengaruh Perubahan Sosial Terhadap Lahan Tidur di Desa Tombasian Atas Kecamatan Kawangkoan Barat. Skripsi Universitas Sam Ratulangi, Manado.

Ummung, Andi, 2014. Pengaruh Modal Sosial Terhadap Pengembangan Usaha Dan Kemandirian Pengrajin Pada Agroindustri Gula Aren Di Kecamatan Ponre Kabupaten Bone. Tesis Universitas Hasanudin, Makassar.

Yustika, Rukavina Baks., 2015. Konsep Ekonomi Kelembagaan Perdesaan, Pertanian, dan Kedaulatan Pangan. Penerbit Empat Dua (Kelompok Intrans Publishing), Malang, Jatim. www.bps.go.id. 19 Feb 2016 